\title{
Patterns of cell proliferation and apoptosis by topographic region in normal Bos taurus vs. Bos indicus crossbreeds bovine placentae during pregnancy
}

\author{
Patricia R Facciotti ${ }^{1}$, Rose EG Rici ${ }^{1}$, Durvanei A Maria², Marcelo Bertolini ${ }^{3}$, \\ Carlos E Ambrósio ${ }^{4}$ and Maria A Miglino*1
}

\begin{abstract}
Address: ${ }^{1}$ Department of Surgery of the São Paulo University, Faculty of Veterinary Medicine and Animal Science, São Paulo, SP, 05508-270, Brazil, ${ }^{2}$ Biochemical and Biophysics Laboratory, Butantan Institute, São Paulo, 05503-900, Brazil, ${ }^{3}$ UDESC - Santa Catarina State University, School of Veterinary Medicine, Lages, Santa Catarina, 88520-000, Brazil and ${ }^{4}$ Department of Basic Science/FZEA, São Paulo University, Faculty of Veterinary Medicine, Pirassununga, SP, 13635-900, Brazil
\end{abstract}

Email: Patricia R Facciotti - patfacciotti@usp.br; Rose EG Rici - roseeli@usp.br; Durvanei A Maria - durvanei@usp.br; Marcelo Bertolini - mbertolini@ymail.com; Carlos E Ambrósio - ceambrosio@usp.br; Maria A Miglino* - miglino@usp.br

* Corresponding author

Published: 30 March 2009

Reproductive Biology and Endocrinology 2009, 7:25 doi:10.1186/1477-7827-7-25

This article is available from: http://www.rbej.com/content/7/1/25

(C) 2009 Facciotti et al; licensee BioMed Central Ltd.

This is an Open Access article distributed under the terms of the Creative Commons Attribution License (http://creativecommons.org/licenses/by/2.0), which permits unrestricted use, distribution, and reproduction in any medium, provided the original work is properly cited.
Received: 29 October 2008

Accepted: 30 March 2009

\begin{abstract}
Background: Placental and fetal growth requires high rates of cellular turnover and differentiation, which contributes to conceptus development. The trophoblast has unique properties and a wide range of metabolic, endocrine and angiogenic functions, but the proliferative profile of the bovine placenta characterized by flow cytometry analysis and its role in fetal development are currently uncharacterized. Complete understanding of placental apoptotic and proliferative rates may be relevant to development, especially if related to the pathogenesis of pregnancy losses and placental abnormalities.
\end{abstract}

Methods: In this study, the proliferation activity and apoptosis in different regions of normal bovine placenta (central and boundary regions of placentomes, placentomal fusion, microplacentomes, and interplacentomal regions), from distinct gestation periods (Days 70 to 290 of pregnancy), were analyzed by flow cytometry.

Results: Our results indicated that microplacentomes presented a lower number of apoptotic cells throughout pregnancy, with a higher proliferative activity by the end of gestation, suggesting that such structures do not contribute significantly to normal of placental functions and conceptus development during pregnancy. The placentome edges revealed a higher number of apoptotic cells from Day 170 on, which suggests that placentome detachment may well initiate in this region.

Conclusion: Variations involving proliferation and apoptotic rates may influence placental maturation and detachment, compromising placental functions and leading to fetal stress, abnormalities in development and abortion, as frequently seen in bovine pregnancies from in vitro fertilization and cloning procedures. Our findings describing the pattern of cell proliferation and apoptosis in normal bovine pregnancies may be useful for unraveling some of the developmental deviations seen in nature and after in vitro embryo manipulations. 


\section{Background}

In ruminants, the placenta is classified as cotyledonary on the basis of its gross anatomical features. The immediate feto-maternal contact in the bovine placenta is restricted to multiple discrete structures called placentomes, consisted of the maternal part, the caruncle, and the fetal part, the cotyledon. In early gestation, caruncles and cotyledons are not connected yet, without formation of placentomes [1-3]. Placentome formation can be considered a gradual process that takes place immediately after pregnancy recognition, being fairly completed by the end of organogenesis [4]. Once established, bovine placentomes grow continuously throughout pregnancy. However, placentome growth varies considerably in the course of gestation. Between days 100-160, placentomes show an accelerated growth pattern, reaching its plateau by around day 199. After this phase, placentome growth decreases progressively [5] and is minimal in late gestation [1]. The growth of the foetal and maternal structures that compose the placentomes are different in feature and are differentially regulated, and the proportion of foetal to maternal tissue is specifically controlled by unknown factors that do not act consistently throughout gestation [6].

Coalescence between two or more neighboring caruncles was observed in Egyptian buffalo cows [7]. Those authors observed that the unusual lobulated shape of caruncles may result from the fusion of four or more adjacent ones. Fusion between the neighboring caruncles occurred only in the fibrillar region and thus deep fissures are found on their free convex surface. Most of the caruncles were found at the antimesometrial region of the uterine horn varying in size, number and shape during all pregnancy phases $[8,9]$. The placentomal fusion presence was also observed in cloned cattle term placenta [10] and was observed a high number of fusions resulting in a increase of placentome size and decrease in numbers.

Bovine normal placentae also presented microplancetomes called accessories placentomes, which have a diameter less than $1.0 \mathrm{~cm}$ and with different numbers both found at the extremities of pregnant or not horns. [1,11].

In the formation of mammalian placenta, many factors must interact in a precise manner to a normal placental development. The uterus increases in size to accommodate the bovine fetus, with the size of the uterus not influencing fetal size [12]. However, maternal uterine environment influences fetal growth and those influences may be mediated, in part, by growth and function of caruncular tissues [13].

Placental growth is complex and influenced by many factors, and it is dependent upon a delicate balance between cell proliferation, differentiation, and death [14]. Consid- ering the distinct macroscopic and functional regions existent at the bovine placenta, diverse patterns of cell proliferation and apoptosis are expected in those regions. A few studies have evaluated the proliferative activity in bovine placentomes $[15,16]$ or the trophoblastic cell density at the end of gestation in cattle [17], but the spatial and temporal profiles for cell proliferation and apoptosis characterized by flow cytometry in the bovine placenta are yet to be described. The understanding of such profiles may assist in sorting out mechanisms leading to placental and fetal abnormalities, especially those associated with certain in vitro embryo manipulations, such as in vitro fertilization (IVF) and cloning by somatic cell nuclear transfer (SCNT) procedures $[4,18]$. Despite their wide use around the world today, such embryo technologies are associated with pre- and postnatal abnormalities, including increased rates of pregnancy losses, hydrops of the fetal membranes, prolonged gestation, diminished signs of parturition, dystocia, and birth of large calves with lower postnatal survival [4]. Placental tissues from cloned bovine gestations had shown more proliferation activity and a reduced rate of apoptosis in the central region of the placentomes and interplacentomal areas that may be associated with the uncommon abnormalities after in vitro embryo manipulations [19]. The appearance of such a diverse range of abnormalities does compromise the practical application of those technologies [20], but also ensures that novel knowledge is gained in mammalian developmental biology, as for one to know the abnormal, the characterization of the normalcy is essential. Therefore, the aim of this study was to characterize normal placenta development during gestation in cattle, describing cell proliferation and apoptotic profiles in distinct topographic regions of the placenta based on the DNA content analysis by flow cytometry. The choice of each placental region was based on different areas in the same placentome (central and edges), interplacentomal areas, placentomal fusion and microplacentome, which show different cell activities during placentation, however with low number of studies in this field.

\section{Methods \\ Animals and tissue sampling}

A total of 28 bovine placentas (Bos taurus vs. Bos indicus crossbreeds) at different gestational phases were collected at a local abattoir. The uterus of each animal was cut open, the fetus removed, and the crown-rump length used to estimate the stage of gestation $[21,22]$. Placentae were divided into four groups of 7 animals each: group I (70 to 120 days), group II (121 to 170 days), group III (171 to 220 days), and group IV (221 to 290 days).

Different regions of each placentae were collected, namely the central region of the placentome, the placentome edges, interplacentomal areas, placentomal fusion, and 
microplacentomes $(\leq 1.0 \mathrm{~cm})$, as illustrated in Figure 1 . Two placental tissue pieces, collected from each placental region from each animal, were gently excised and cut into numerous small fragments of around $0.5 \mathrm{~cm}$, to be immediately plunged into liquid nitrogen and subsequently used for flow cytometry analysis. Due the anatomical particularities of interplacentomal region during the mechanic dissection, myometrium was gently extracted and kept the total tissue with fetal and maternal epithelia, also fetal mesenchyme for flow citometry analyses. All placental tissue pieces contained both maternal and foetal tissue, including connective tissue and uterine and trophoblastic epithelia. Therefore, the flow cytometric analysis was performed on a cell population composed largely of epithelial cells, with a rare proportion of maternal stroma and foetal mesenchyme, such as fibroblasts and endothelial cells. The uterine subepithelial cell in bovines is richly vascularized and composed by a great amount of fibrocytes [23], which are in quiescent metabolic status [24], and not significantly interfering on the proportion of cells in the proliferation $(\mathrm{S}, \mathrm{G} 2 / \mathrm{M})$ or in apoptosis.

\section{Flow cytometry analysis - DNA content and cell cycle distribution}

Fragments stored in liquid nitrogen were placed in citrate buffer, $\mathrm{pH} 7.6$, and processed according to previous experiments [25], being subsequently filtered through a $30 \mu \mathrm{m}$ mesh (Spectra Mesh Nylon Filters, Sigma Chemical Co., St. Louis, MO, USA) to separate proteins (a large component of the tissue stroma, or connective tissue) and cell debris, composed of blood cells, degenerating/degener-

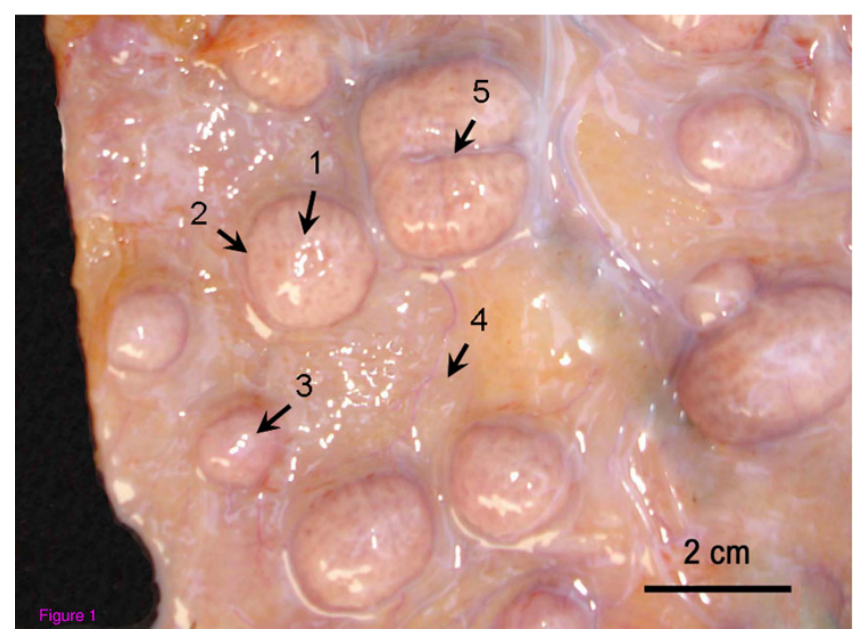

Figure I

Representation of the distinc placental regions from which tissue samples were collected for flow cytometry analysis. (I) Central region of the placentome, (2) Placentome edges, (3) Microplacentome, (4) Interplacentomal region, (5) Placentomal fusion. Bovine pregnant tract at 122 days of gestation. ated cells and adipose tissue. Samples were incubated in $30 \mathrm{mg} / \mathrm{mL}$ trypsin (Sigma Chemical Co.) for $10 \mathrm{~min}$ at room temperature. Then, $5 \mathrm{mg} / \mathrm{mL}$ trypsin inhibitor (Sigma Chemical Co.) and $0.1 \mathrm{mg} / \mathrm{mL}$ of ribonuclease A (Sigma Chemical Co.) were added for $10 \mathrm{~min}$ at room temperature (for optimal DNA resolution), and $415 \mu \mathrm{g} /$ $\mathrm{mL}$ propidium iodide (Sigma Chemical Co.) was added 15 min before the flow cytometry analysis. At least 10,000 events were acquired using Cell Quest Software (Beckton Dickinson, San Jose, CA, USA). The DNA content was measured using a FACScalibur Flow Cytometer (Beckton Dickinson) equipped with an air-coupled 15-mW, 488$\mathrm{nm}$ argon ion laser. The percentage of cells in each phase of the cell cycle, namely apoptosis (sub-G1, DNA fragmentation), G0/G1 (quiescent cells), synthesis (S), and G2/M (proliferative phase) was determined with ModFit Software analyses (Beckton Dickinson).

Data from cytometry experiments were subjected to oneway ANOVA followed by pairwise multiple comparison procedures (Student-Newman-Keuls method) using GraphPad Instat 3.0 software.

\section{Results}

The cell cycle analysis was performed in placental tissues throughout pregnancy, starting at a time when placentomes are already well formed. The percentage of cells in each phase of the cell cycle for each topographic region of the bovine placenta by group is displayed in Table 1 .

In group I, a lower number of $\mathrm{G} 2 / \mathrm{M}$ cells $(\mathrm{P}<0.05)$ and a higher number of G0/G1 cells $(\mathrm{P}<0.05)$ were observed in microplacentomes and placentomal fusions in comparison with the interplacentomal region and the edges of the placentomes, indicating a lower proliferative activity in the former structures, along with a lower cell death rate. In this gestational group, the incidence of apoptotic cells were lower in microplacentomes $(\mathrm{P}<0.05)$ in comparison with the other placental regions (Figure 2a).

Significant variations remained on microplacentomes and placentomal fusions on Group II, as shown in Figure 2b. Those structures remained with a lower number of cells in proliferative activity in relation to the other regions, demonstrating significantly lower values for cells in G2/M phase $(P<0.05)$ and higher number of cells in G0/G1 phase $(\mathrm{P}<0.01)$. The number of apoptotic cells was also lower in microplacentomes in relation to the other regions $(P<0.05)$, except the central region of placentome. However, a lower number of apoptotic cells were also observed in placentomal fusions in Group II, indicating a lower cell death rate.

In Group III, the number of G0/G1 cells differed significantly in the edges of placentomes $(\mathrm{P}<0.05)$ and in total 
Table I: Distribution of the cell cycle phases (in \%) in distinct topographic regions of placentae at different stages of gestation in cattle

\begin{tabular}{|c|c|c|c|c|c|c|c|}
\hline \multirow[b]{3}{*}{ Cell cycle phase } & \multirow[b]{3}{*}{$\begin{array}{l}\text { Groups: Days in } \\
\text { gestation }\end{array}$} & \multicolumn{6}{|l|}{ Placental region } \\
\hline & & Placentome & & & & & \\
\hline & & Total* & Central region & Edges & $\begin{array}{l}\text { Interplacentomal } \\
\text { region }\end{array}$ & Microplacentomes & $\begin{array}{l}\text { Placentomal } \\
\text { fusion }\end{array}$ \\
\hline \multirow[t]{4}{*}{$\mathrm{G} 2 / \mathrm{M}$} & G-I: 70 to 120 & $20.0 \pm 11.4^{\mathrm{a}, \mathrm{b}}$ & $16.7 \pm 7.0 \mathrm{a}, \mathrm{b}$ & $23.4 \pm 15.9 a$ & $23.6 \pm 3.1^{\mathrm{a}}$ & $8.9 \pm 6.2^{\mathrm{b}, \mathrm{B}}$ & $7.7 \pm 4.3^{b}$ \\
\hline & G-II: $12 \mid$ to 170 & $20.3 \pm 10.2^{\mathrm{a}}$ & $18.9 \pm 9.3^{a}$ & $21.7 \pm 11.1^{a}$ & $18.3 \pm 9.3^{a}$ & $7.7 \pm 2.1^{b}, B$ & $5.4 \pm 3.4^{b}$ \\
\hline & G-III: $|7|$ to 220 & $21.6 \pm 12.1 \mathrm{a}, \mathrm{b}$ & $19.6 \pm 13.7^{a, b}$ & $23.6 \pm 10.6^{a}$ & $17.6 \pm 9.4 \mathrm{a}, \mathrm{b}$ & $13.1 \pm 12.4^{a}, b$ & $7.3 \pm 4.1^{b}$ \\
\hline & G-IV: 221 to 290 & $18.8 \pm 7.7$ & $18.6 \pm 5.9$ & $19.0 \pm 9.6$ & $18.5 \pm 6.5$ & $21.8 \pm 8.4^{\mathrm{a}}$ & $12.1 \pm 11.3$ \\
\hline \multirow[t]{4}{*}{ S } & G-I: 70 to 120 & $5.6 \pm 3.5$ & $5.7 \pm 3.4$ & $5.5 \pm 3.6$ & $5.6 \pm 2.5$ & $3.7 \pm 3.1$ & $3.1 \pm 0.3$ \\
\hline & G-II: $12 \mid$ to 170 & $4.4 \pm 0.9$ & $4.6 \pm 0.9$ & $4.1 \pm 1.1$ & $3.0 \pm 1.4$ & $3.2 \pm 0.7$ & $3.4 \pm 1.1$ \\
\hline & G-III: $17 \mid$ to 220 & $7.4 \pm 4.6$ & $10.2 \pm 7.4$ & $4.5 \pm 1.8$ & $5.0 \pm 4.2$ & $5.5 \pm 4.6$ & $3.6 \pm 1.6$ \\
\hline & G-IV: 221 to 290 & $5.6 \pm 3.3$ & $8.2 \pm 4.9$ & $3.0 \pm 1.8$ & $3.7 \pm 2.6$ & $4.4 \pm 3.9$ & $3.0 \pm 1.5$ \\
\hline \multirow[t]{4}{*}{ G0/GI } & G-I: 70 to 120 & $63.7 \pm 16.3^{\mathrm{a}, \mathrm{b}}$ & $67.0 \pm 13.8 \mathrm{a}, \mathrm{b}$ & $60.4 \pm 18.9 a$ & $57.0 \pm 9.1^{\mathrm{a}}$ & $84.3 \pm 11.8^{b}$ & $80.5 \pm 10.9 b$ \\
\hline & G-II: 121 to 170 & $60.5 \pm 18.1^{a}$ & $64.6 \pm 13.8^{a}$ & $56.5 \pm 22.3^{a}$ & $64.3 \pm 18.3^{a, b}$ & $86.4 \pm 2.0^{b}$ & $87.7 \pm 3.9 b$ \\
\hline & G-III: $|7|$ to 220 & $54.2 \pm 20.7^{a}$ & $62.2 \pm 18.1 \mathrm{a}, \mathrm{b}$ & $46.2 \pm 23.4^{\mathrm{a}}$ & $67.6 \pm 15.7 \mathrm{a}, \mathrm{b}$ & $78.8 \pm 18.5^{b}$ & $83.0 \pm 7.1^{b}$ \\
\hline & G-IV: 221 to 290 & $56.1 \pm 17.8$ & $62.5 \pm 10.0$ & $49.8 \pm 25.7$ & $65.1 \pm 15.8$ & $71.2 \pm 11.0$ & $73.5 \pm 22.1$ \\
\hline \multirow[t]{4}{*}{ Apoptosis } & G-I: 70 to 120 & $10.7 \pm 8.5^{\mathrm{a}}$ & $10.6 \pm 8.5^{a}$ & $10.7 \pm 8.5^{\mathrm{a}}$ & $13.7 \pm 9.8^{a}$ & $3.0 \pm 2.6^{b}$ & $8.6 \pm 8.5^{a}$ \\
\hline & G-II: $|2|$ to $\mid 70$ & $14.8 \pm 8.9^{a}$ & $12.0 \pm 5.7^{a, b}$ & $17.7 \pm 13.3^{\mathrm{a}}$ & $14.4 \pm 8.9 \mathrm{a}$ & $2.7 \pm 0.4^{b}$ & $3.5 \pm 0.7^{b}$ \\
\hline & G-III: $17 \mid$ to 220 & $16.9 \pm 7.9 \mathrm{a}, \mathrm{b}$ & $8.0 \pm 3.7 b$ & $25.7 \pm 13.9 \mathrm{a}$ & $9.7 \pm 8.2^{b}$ & $2.7 \pm 2.1^{b}$ & $6.1 \pm 3.3^{b}$ \\
\hline & G-IV: 221 to 290 & $19.5 \pm 8.3^{a, b}$ & $10.7 \pm 4.7^{b}$ & $28.2 \pm 17.2^{\mathrm{a}}$ & $12.7 \pm 10.3^{b}$ & $2.6 \pm 1.1^{b}$ & $11.4 \pm 9.4^{b}$ \\
\hline
\end{tabular}

a-e Values (mean $\pm S D$ ) in the same row with different superscripts differ $(P<0.05)$.

A-E Values (mean $\pm S D$ ) in the same column with different superscripts differ $(P<0.05)$.

* Total means: central plus edges region of placentome

placentome (central region plus edges) in relation to microplacentomes and placentomal fusions (Figure 2c). The number of G2/M cells was significantly higher in the edges of placentomes $(\mathrm{P}<0.01)$ in relation to placentomal fusions. Surprisingly, there were a significantly higher number of apoptotic cells in those boundary areas in groups III and IV $(\mathrm{P}<0.001)$, except the total placentome related to central region plus edges areas.

Significant variations were observed in numbers of apoptotic cells in Group IV, as shown Figure 2d. The incidence of apoptotic cells was significantly higher in the placentome edges $(\mathrm{P}<0.001)$ in relation to the other regions, except the total placentome (central region + edges).

There were no significant differences in proliferation activity between the interplacentomal region and the central region of placentome, those regions revealed similar values in both cell cycle phases and gestational groups.

\section{Discussion}

Our findings by flow cytometric analysis indicated variations in proliferation and apoptosis in different placental regions at each gestational phase. Analyzing the cell cycle phases were found a high standard deviation among the samples, probably due to the high variation of chorionic:uterine cells proportion. However, we aimed to determine the proliferative activity and apoptosis in all studied placental regions like as maternal and fetal tissue and the high standard deviation were expected.
By analyzing the total placentomes, area, i.e., cells from the edge and from the central placentome region, we observed a proliferative activity that was inversely proportional to the apoptotic rate throughout gestation, which was not detected when regions were analyzed separately. According to a previous report [16], apoptosis reflects the beginning of tissue regeneration and continuing histiotrophic nutrition to the fetus, which consists in phagocytosis of maternal apoptotic epithelial cells. Such variations are considered part of the placental maturation process, which can be a requirement to materno-fetal detachment and fetal membranes release $[1,16]$. Such variations were not detected in term placentas from clone cattle. Using flow cytometry, [19] showed more proliferation activity and a reduced rate of apoptosis in the central region of the placentomes and interplacentomal areas. Such phenomena may be associated with faulty placentation in early pregnancy, placental insufficiency or even a lack of placental and/or fetal maturation towards the end of pregnancy.

When placentome's edges were analyzed separately from the central region of the placentome, a premature increase in apoptotic cells was detected, with a significantly higher number of apoptotic cells than in the other regions as pregnancy progressed, well observed in Groups III and IV. According to [16], the large number of apoptotic cells by the end of gestation occurs as a mechanism associated with maternal-fetal detachment. Therefore, the high number of apoptotic cells in the placentome's edge from 

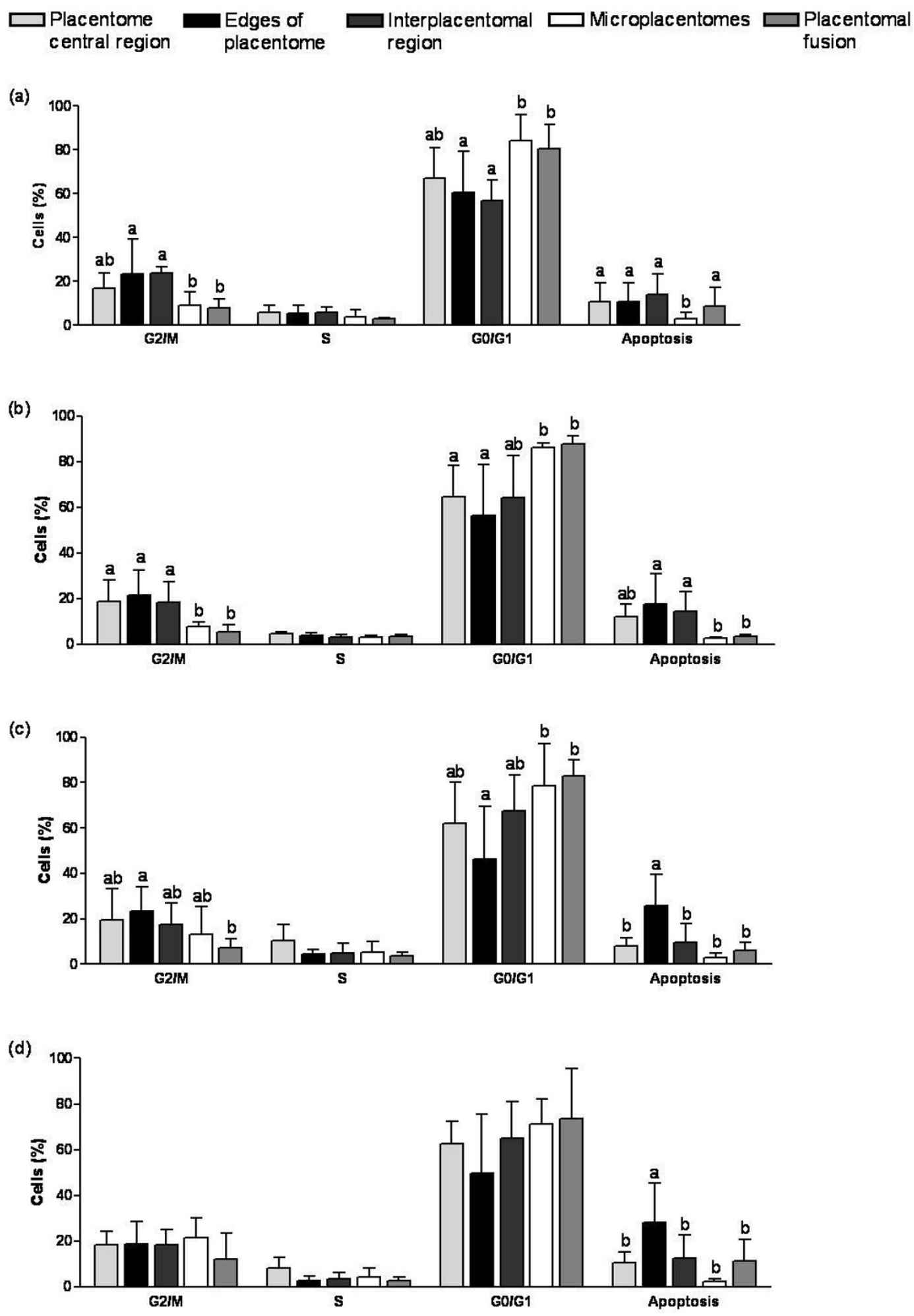

Figure 2

Distribution of the phases of the cell cycle (G2/M, S, G0/GI, apoptosis) in distinct placental regions. (a) Group I (Days 70 to I20 of gestation), (b) Group II (Days I2I to I70 of gestation), (c) Group III (Days I7I to 220 of gestation), (d) Group IV (Days 22 I to 270 of gestation). ${ }^{\mathrm{a}-\mathrm{b}}$ Bars with different superscripts differ; $\mathrm{P}<0.05$. 
170 days on suggests this region to be the point of initiation of placentomal detachment in cattle. In this context, the edges of placentome may play an important role in placental maturation and release. These results suggest that placentomal detachment occurs in a centripetal way; therefore, the placentomal maturation occurs from the edges to the center of the placentomes.

TUNEL procedure and Ki-67 proliferation maker demonstrated proliferation not to be the main factor responsible for growth in interplacentomal uterine wall, including adherent fetal membranes, which predominantly should be achieved by hypertrophy [26]. Findings from that study gives support to ours for the interplacentomal region, which showed no significant variations during pregnancy, suggesting that proliferation is of minor importance for tissue homeostasis in the interplacentomal region.

In this study, microplacentomes showed different proliferative patterns throughout pregnancy. The G2/M cells increased in numbers throughout gestation, with significative variations in groups I and II in relation to group IV, suggesting cell cycle progression from a quiescent to a proliferative state. On the other hand, the proportion of apoptotic cells in microplacentomes remained low in all gestational periods, with percentile values being significantly lower than the other studied regions in Group I; the total placentome (central region + edges), the placentome's edges and interplacentomal region in Group II; and the placentome's edges in Groups III e IV. Such results suggest microplacentomes to have a slower proliferation activity in Groups I and II, which could be linked to its limited size in bovine placenta. Apparently, such structures remain at a quiescent state in group I, with low tissue plasticity or remodeling, not following the pattern of maturation and growth seen in normal placentomes. Most likely, the observations above are related to the relatively small role of those structures, with microplacentomes not contributing significantly to normal of placental functions and conceptus development during pregnancy.

Placentomal fusion showed a lower proliferative activity in Groups I and II compared to the other regions, which was similar to microplacentomes. The number of proliferative cells increases on Group IV, however, the number of apoptotic cells also increases in the same period, demonstrating a balance between proliferative and apoptotic cells number in placentomal fusion. The region of fusion is composed by endometrial stromal axis [8], formed by cells in a balance/equilibrium state of proliferative activity, suggesting maternal stromal axis have a functional role in physiological maintenance of gestation, however, a little contribution to maturation and placental release.

Abnormal placental development has been implicated as the main factor limiting the success in ruminant pregnan- cies derived from IVF and cloning procedures by SCNT $[4,18]$. Recent studies have described structural and microvascular architecture distinctions in bovine IVF and clone placentae $[10,27]$, with the description of increased number of functional and accessory microcotyledons, dilated caruncular crypts accommodating more than one primary villous with a lack of dense complexes of capillary loops and sinusoidal dilations, abnormal vascularization, tissue remodeling, differentiation and maturation of placental tissue in mid- to late pregnancy. In that period, any alteration in placenta development may affect fetal development and the success of gestation [28], with disturbances in programmed cell death in placenta seeming to be associated with an abnormal pregnancy outcome [2932]. Taken together, the complete understanding of placental apoptotic and proliferative profiles at distinct placental tissue regions during gestation will shed light to unknown physiological processes related to conceptus development, as some regions may be potentially responsible, at different degrees of influence, to distinct modulation patterns in fetal growth and nutrition throughout pregnancy. In that regard, results from the present study using non-manipulated and crossbreed bovine gestations indicated that proliferation and apoptosis exhibit patterns that are specific for the individual placental areas during gestation and at term in normal, non-manipulated pregnancies in cattle.

\section{Competing interests}

The authors declare that they have no competing interests.

\section{Authors' contributions}

PRF, REGR, DAM and MAM collected the materials, established the pregnancy groups, performed the cytometry analysis, carried out the experiment and wrote major parts of the manuscript. $\mathrm{MB}$ wrote parts of the manuscript regarding the physiology of reproduction. CEA, MB and MAM reviewed the manuscript and the quality of the written English. All authors read and approved the final manuscript.

\section{Acknowledgements}

This study received financial support from Fundação de Amparo à Pesquisa do Estado de São Paulo (FAPESP, process number 2007/59744-8 and 2007/ 52137-9). We gratefully acknowledge Frigorífico Mantiqueira, which provided the animals for this study.

\section{References}

I. Bjorkman N: Morphological and histochemical studies on the bovine placenta. Acta Anat 1954, 22: I-91.

2. Leiser R: Development of contact between trophoblast and uterine epithelium during the early stages on implantation in the cow. Zentralbl Veterinarmed 1975, 4:63-86.

3. Leiser R, Kaufmann P: Placental structure: in a comparative aspect. Exp Clin Endocrinol 1994, 102:122-134.

4. Bertolini M, Bertolini LR, Gerger RPC, Batchelder CA, Anderson GB: Developmental problems during pregnancy after in vitro embryo manipulations. Rev Bras Reprod Anim 2007, 3 I :39 I-405.

5. Reynolds LP, Millaway DS, Kirsch JD, Infeld JE, Redmer DA: Growth and in vitro metabolism of placental tissues of cows from day 100 to day 250 of gestation. J Reprod Fertil 1990, 89:2 I3-222. 
6. Laven RA, Peters RA: Gross morphometry of the bovine placentome during gestation. Reprod Dom Anim 200I, 36:289-296.

7. Abdel-Raouf M, Badawi HM: Morphological study of uterine caruncles in Egyptian buffalo cows. Zbl Vet Med 1965, 1 3:252-263.

8. Pereira FTV, Barreto RSN, Miglino MA, Silva SM, Burioli KC: Fusão caruncular em vacas prenhes. Acta Sci Vet 2006, 34:586.

9. Cazerta SMM, Miglino MA, Marques RS, Vulcano M, Pereira FTV: Caracterização das áreas hemófagas da placenta bovina. Pesq Vet Bras 2007, 27:229-235.

10. Miglino M, Pereira F, Visintin J, Garcia J, Meirelles F, Rumpf R, Ambrosio C, Papa P, Santos T, Carvalho A: Placentation in cloned cattle: Structure and microvascular architecture. Theriogenology 2007, 68:604-617.

II. Andresen A: Die plazentome der wiederkauer. Morphologisches Jahrbuch 1927, 57:410-485.

12. Prior RL, Laster DB: Development of the bovine foetus. J Anim Sci 1979, 48: I546-I553.

13. Ferrel CL: Maternal and fetal influences on uterine and conceptus development in the cow: growth of tissues of the gravid uterus. J Anim Sci 1991, 69:1945-1953.

14. Hale AJ, Smith CA, Sutherland LC, Stoneman VEA, Longthorne VL, Culhane AC, Williams GT: Apoptosis: molecular regulation of cell death. Eur J Biochem 1996, 236:I-26.

15. Schuler G, Wirth C, Klisch K, Failing K, Hoffmann B: Characterization of Proliferative Activity in Bovine Placentomes Between Day 150 and Parturition by Quantitative Immunohistochemical Detection of Ki67-Antigen. Reprod Dom Anim 2000, 35:157-162

16. Boos A, Janssen V, Mülling C: Proliferation and apoptosis in bovine placentomes during pregnancy and around induced and spontaneous parturition as well as in cows retaining the fetal membranes. Reproduction 2003, I 26:469-480.

17. Miles JR, Farin CE, Rodriguez KF, Alexander JE, Farin PW: Angiogenesis and morphometry of bovine placentas in late gestation from embryos produced in vivo or in vitro. Biol Reprod 2004, 71:1919-1926.

18. Lonergan P, Evans ACO, Boland E, Rizos D, Fair T, Duffy P, Sung LY, Duc F, Chaubal S, Xu J, Yang X, Tian XC: Pregnancy and fetal characteristics after transfer of vitrified in vivo and cloned bovine embryos. Theriogenology 2007, 68: II I28-II37.

19. Rici REG, Facciotti PR, Ambrósio CE, Maria DA, Kfoury JR Jr, Bertolini M, Miglino MA: Cell cycle and apoptosis in normal and cloned bovine near-term placentae. Anim Reprod Sci 2008 in press. 2008 Nov 27

20. Young LE, Sinclair KD, Wilmut I: Large offspring syndrome in cattle and sheep. Rev Reprod 1998, 3:155-163.

21. Richardson C: Veterinary reproduction and obstetrics 6 th edition. Edited by: Arthur GH. Noakes DE, Pearson H. London: Bailliére Tindal; 1989.

22. Assis Neto AC, Pereira FTV, Santos TC, Ambrosio CE, Leiser R, Miglino MA: Morpho-physical Recording of Bovine Conceptus (Bos indicus) and Placenta from Days 20 to 70 of Pregnancy. Reprod Domest Anim 2009 in press. 2009 Feb 25

23. Priedklns J, Leiser R: Female Reproductive System. In Textbook of Veterinary Histology 5th edition. Edited by: Dellmann HD, Eurell J. Philadelphia: Lippincott Williams \& Williams; 1998:247-286.

24. Kierszenbaum AL: Histology and cell biology. An introduction to pathology. Mosby: St Louis; 2002:106-108.

25. Vindelov LL, Christensen IJ, Nissen NI: A detergent-trypsin method for the preparation of nuclei for flow cytometric DNA analysis. Cytometry 1983, 3:323-327.

26. Boos A, Kohtes J, Janssen V, Mülling C, Stelljes A, Zerbe H, Hässig M, Thole $\mathrm{HH}$ : Pregnancy effects on distribution of progesterone receptors, oestrogen receptor, glucocorticoid receptors, Ki67 antigen and apoptosis in the bovine interplacentomal uterine wall and foetal membranes. Anim Reprod Sci 2006, 9I:55-76.

27. Miles JR, Farin CE, Rodriguez KF, Alexander JE, Farin PW: Effects of embryo culture on angiogenesis and morphometry of bovine placentas during early gestation. Biol Reprod 2005, 73:663-67I.

28. Redmer DA, Wallace JM, Reynolds LP: Effect of nutrient intake during pregnancy on fetal and placental growth and vascular development. Domest Anim Endocrinol 2004, 3:199-217.

29. Runic R, Lockwood CJ, Ma Y, DiPasquale B, Guller S: Expression of Fas ligand by human cytotrophoblast: implications in placen- tation and foetal survival. I Clin Endocrinol Metabol 1996 8I:3III-3I22.

30. Hunt JS, Vassmer D, Ferguson TA, Miller L: Fas ligand is positioned in mouse uterus and placenta to prevent trafficking of activated leukocytes between the mother and the conceptus. J Immunol 1997, I 58:4I22-4I28.

3I. Uckan D, Steele A, Cherry A: Trophoblasts express Fas ligand: a proposed mechanism for immune privilege in placenta and maternal invasion. Mol Hum Reprod 1997, 3:655-662.

32. Guller S, Lachapelle L: The role of placental Fas ligand in maintaining immune privilege at maternal-foetal interfaces. Semin Reprod Endocrinol 1999, I7:39-44.
Publish with Bio Med Central and every scientist can read your work free of charge

"BioMed Central will be the most significant development for disseminating the results of biomedical research in our lifetime. "

Sir Paul Nurse, Cancer Research UK

Your research papers will be:

- available free of charge to the entire biomedical community

- peer reviewed and published immediately upon acceptance

- cited in PubMed and archived on PubMed Central

- yours - you keep the copyright

Submit your manuscript here:

http://www.biomedcentral.com/info/publishing_adv.asp 